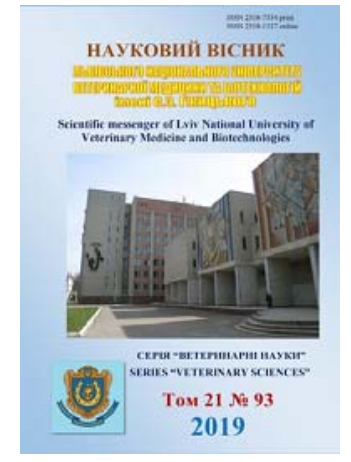

Науковий вісник Дьвівського національного університету ветеринарної медицини та біотехнологій імені С.З. Гжицького.

\author{
Серія: Ветеринарні науки
}

Scientific Messenger of Lviv National University of Veterinary Medicine and Biotechnologies. Series: Veterinary sciences

UDC 619:616.984

\title{
Pathomorphological changes in parenchymatose organs of rabbits in case of chronic passalurosis
}

\author{
S.M. Mykhailiutenko ${ }^{1}$, O.V. Kruchynenko ${ }^{1}$, J.K. Serdioucov ${ }^{2}$, O.S. Klymenko ${ }^{1}$, J.D. Popovytch ${ }^{2}$ \\ ${ }^{1}$ Poltava State Agrarian Academy, Poltava, Ukraine \\ ${ }^{2}$ National University of life and environmental sciences of Ukraine, Kyiv, Ukraine
}

\section{Article info}

Received 22.01.2019

Received in revised form 28.02.2019

Accepted 01.03.2019

Poltava State Agrarian Academy, Skovorody Str., 1/3, Poltava, 36003, Ukraine.

Tel.: +38-066-630-54-44

E-mail:sv81@ukr.net

National University of Life and Environmental Sciences of Ukraine Heroyiv Oborony Str., 15, Kyiv, 03041, Ukraine.

\begin{abstract}
Mykhailiutenko, S.M., Kruchynenko, O.V., Serdioucov, J.K., Klymenko, O.S., \& Popovytch, J.D. (2019). Pathomorphological changes in parenchymatose organs of rabbits in case of chronic passalurosis. Scientific Messenger of Lviv National University of Veterinary Medicine and Biotechnologies. Series: Veterinary sciences, 21(93), 31-36. doi: 10.32718/nvlvet9306
\end{abstract}

Pathomorphological changes, developing in case of pasalurosis chronic course in rabbits are described in the article. The research was held on ten rabbits of Large Grey breed, which were held on household farms of Poltava region. The diagnosing was complex: based on anamnesis data, clinical symptoms' analysis, and the results of pathomorphological examination. The fragments of the liver, spleen, and kidneys were taken for histological analysis. While making histological analysis of the spleen it was revealed that lymphoid nodules were enlarged, some of them were of uniform structure, and others were in the state of hyperplasia. Non-uniformity of structure in addition to changing the size was registered in those nodules: there was less concentration of lymphoid cells in their central part and more concentration on the periphery. The situation was contrary in separate lymphoid nodules. The red pulp consisted of a large number of lymphoid cells and erythrocytes, the largest number of which were registered in the zones adjoining the places of lymphoid nodules' location. Sometimes there were megakaryocytes in the field of vision. It was established, that blood filling of arteries was less than normal. In case of using some preparations, bilirubin inclusions were found at having big enlargements in red pulp. Grainy and fatty hepatocytes' dystrophies, and also lymphohistiocytic interstitial hepatitis were also registered. At the same time, renal corpuscles were enlarged. Rather big spaces, filled with transparent substance containing vessel and cellular fragments (detritus), were revealed in the majority of them between glomeruli and the capsule.Capsule epithelial cells were destroyed in some places. Petechial hemorrhages were registered inside glomeruli. The destruction of separate podocytes and deep cells was noticed. The tubular epithelial cells were enlarged in size, and in some cases they were of cylinder, but not cubic shape; the spaces of such tubular were becoming correspondingly less. The epithelial cell cytoplasm of the tubular in some cases was not uniformand it was of cloudy-grey color: in other cases it had rather large colorless areas and, probably, looked like lipid inclusions (which were washed out from the cells as a result solvent impact during making histological preparations). Concentrations of eosinophilic masses (protein cylinders) sometimes containing certain amount of erythrocytes were often found in canaliculi spaces. Sometimes the destruction of epithelial cells was registered in the tubules, and their fragments were found in spaces. As a result of histological examination, the diffuse lymphohistiocytic infiltration in the renal interstitial tissue was found.

Key words: rabbits, passalurosis, histological changes, liver, kidneys, spleen.

\section{Патоморфологічні зміни в паренхіматозних органах кролів за хронічного перебігу пасалурозу}

\author{
С.М. Михайлютенко ${ }^{1}$, О.В. Кручиненко ${ }^{1}$, Я.К. Сердюков ${ }^{2}$ О.С. Клименко ${ }^{1}$, Ю.Д. Попович ${ }^{2}$ \\ ${ }^{1}$ Полтавська державна аграрна академія, м. Полтава, Украӥна \\ ${ }^{2}$ Національний університет біоресурсів і природокористування України, м. Київ, Украйна
}


У статті описано патоморфологічні зміни, щзо розвиваються за хронічного перебігу пасалурозу кролів. Дослідження проведено на 10 кролях породи сірий велетень, які утримувались у домашніх умовах в одноосібних господарствах Полтавської області. Діагноз встановлено комплексно: на основі даних анамнезу, аналізу клінічних ознак, результатів патолого-анатомічного дослідження. Для мікроскопії відібрано зразки печінки, селезінки та нирок. За гістологічного дослідження селезінки встановлено, шзо лімфоїдні вузлики збільшені в розмірах, деякі з них мали однорідну будову, деякі були в стані гіперплазії. В таких вузликах, окрім змін в розмірах, зареєстровано неоднорідність структури: в центральній їхній частині виявлено меншу концентрацію лімфоїдих клітин, по периферї - більиу концентрачію. В окремих лімфоїдних вузликах - навпаки. Червона пульпа складалася з великої кількості лімфоїдних клітин та еритроцитів, найбільшу кількість яких зафіксовано у зонах, щзо прилягали до місиь розташування лімфоїних вузликів. Подекуди в полі зору траплялися мегакаріоцити. Встановлено, щуо кровонаповнення артерій менше, ніж у нормі. На деяких препаратах за великих збільшень в червоній пульпі виявлено включення білірубіну. Також реєстрували зернисту й жирову дистрофії гепатоцитів та лімфогістіоцитарний інтерстиційний гепатит. Водночас ниркові тільця збільиені в розмірах. У більшості з них між судинними клубочками та капсулою виявлено досить великі простори, заповнені прозорою субстанцією, цзо містила фрагменти судин та клітин (детрит). Епітеліочити капсули подекуди зруйновані. Всередині клубочків зареєстровано крапкові крововиливи. Спостерігали руйнування окремих подоцитів та мезангіоцитів. Епітеліоцити канальців збільшені в розмірах $і$ подекуди мали не кубічну, а цүиіндричну форму, просвіти таких канальців відповідно зменшені. Цитоплазма епітеліоцитів канальців в одних випадках була неоднорідною, мутно-сірою; в іниих -мала досить великі ділянки, які не зафарбовувалися і, вочевидь, являли собою включення ліпідів (які вимиваються з клітин внаслідок дї розчинників під час виготовлення гістопрепаратів). У просвітах канальців часто виявляли скупчення еозинофільної маси (білкові циліндри), які інколи містили й певну кількість еритроцчитів. Іноді в канальиях спостерігали руйнування епітеліоцитів, фрагменти яких містилися в просвіті. Гістологічним дослідженням встановлено наявність дифузної лімфогістіоцитарної інфільтрації в інтерстиційній тканині нирок.

Ключові слова: кролі, пасалуроз, гістологічні зміни, печінка, нирки, селезінка.

\section{Вступ}

Кролівництво - перспективна галузь, одна з найприбутковіших у сільському господарстві. Негативним аспектом у розведенні кролів $\epsilon$ те, що вони дуже сприйнятливі до багатьох інфекційних (Laakkonen et al., 2006; Kos'yanchuk, 2017) та інвазійних хвороб (Darzi et al., 2007; Sürsal et al., 2014; Okumu et al., 2014).

Значний ряд повідомлень науковців свідчить, що в організмі як диких, так свійських кролів одночасно може локалізуватись кілька видів паразитів (Szkucik et al., 2014; Ola-Fadunsin et al., 2018). Останні діють патогенно на органи й тканини, призводячи до зменшення приросту маси, передчасного забою та навіть летальності (Lello et al., 2005; Eira et al., 2007; Sharma et al., 2017).

Однією з таких хвороб є пасалуроз (passalurosis) поширене хронічне інвазійне захворювання зайцеподібних, яку спричиняє нематода, що паразитує в кишечнику, з родини Oxyuridae - Passalurus ambiquus. Хвороба клінічно проявляється інтенсивним свербежем шкіри навколо ануса, різноманітними порушеннями процесу травлення, схудненням. За високої інтенсивності інвазії спостерігають загибель (Florian, 1997; Rewatkar et al., 2013; Motamedi et al., 2014). Призводять до виникнення виникненню хвороби незадовільні умови годівлі та утримання тварин. Екстенсивність інвазії нерідко сягає 40-90\%, інтенсивність інвазіï - до тисячі гельмінтів (Nagashyan \& Tscherbakov, 2005). Найчастіше хворіють кролі у віці 4-12 міс. Інтенсивність інвазії може зростати внаслідок самоперезараження при розчісуванні хворими тваринами ділянки навколо ануса. Реінвазії сприяе притаманне кролям явище копрофагії.

Незважаючи на значне поширення пасалурозу кролів, не висвітлені дані щодо впливу інвазії Passalurus ambiguus на мікроскопічну будову органів та тканин тварин. Хоча для запобігання хвороби необхідно проводити своєчасну діагностику, в тому числі й морфологічну (Elshahawy \& Elgoniemy, 2018).
Мета роботи полягала у вивченні патоморфологічних змін у паренхіматозних органах кролів за умови впливу на їхній організм пасалурисів, визначення особливостей мікроскопічної будови цих органів за хронічного перебігу захворювання.

\section{Матеріал і методи досліджень}

Дослідження проводились упродовж 2017 2018 років на базах кафедри анатомії, гістології і патоморфології тварин ім. академіка В.Г. Касьяненка (Національний університет біоресурсів і природокористування України) та наукової лабораторії кафедри паразитології та ветеринарно-санітарної експертизи (Полтавська державна аграрна академія).

Досліди провели на 10 вимушено забитих кролях породи сірий велетень, які утримувались у домашніх умовах. Патолого-анатомічний розтин виконували методом повного гельмінтологічного розтину окремих органів за К.І. Скрябіним. Для гістологічних досліджень відібрали зразки печінки, селезінки та нирок (Goral's'kyj et al., 2005; Zon et al., 2009).

Відібрані шматочки фіксували в 10\% забуференому нейтральному розчині формаліну, заливали в парафін. Гістозрізи виготовляли на санному мікротомі НМ-440Е, фарбували гематоксиліном Караці та еозином. Мікрофотографування здійснювали 3 використанням світлового бінокулярного мікроскопа micros mcq 2000 із системою аналізу зображення за допомогою програми “Відео Тест”.

\section{Результати та їх обговорення}

Макроскопічно селезінка в досліджуваних тварин була темно-червона, краї гострі, консистенція ущільнена, поверхня розрізу зерниста. Печінка - червонокоричнева, із окремими блідо-жовтими ділянками, консистенція в'яла, на розрізі помірно волога. Нирки - коричневі, консистенція пружна, на розрізі помірно вологі, межа між кірковим і мозковим шарами чітко виражена, кірковий шар мав жовтуватий відтінок. 
За мікроскопічного дослідження селезінки виявлено, що лімфоїдні вузлики були збільшені в розмірах, деякі з них мали однорідну будову, деякі були в стані гіперплазії. В таких вузликах, окрім змін в розмірах, спостерігали неоднорідність структури: в центральній їхній частині виявляли меншу концентрацію лімфоїдних клітин, по периферії - більшу концентрацію. В окремих лімфоїдних вузликах, навпаки, більша концентрація лімфоїдних клітин спостерігалася в центральній частині (рис. 1). Розташовані вони були поодиноко.

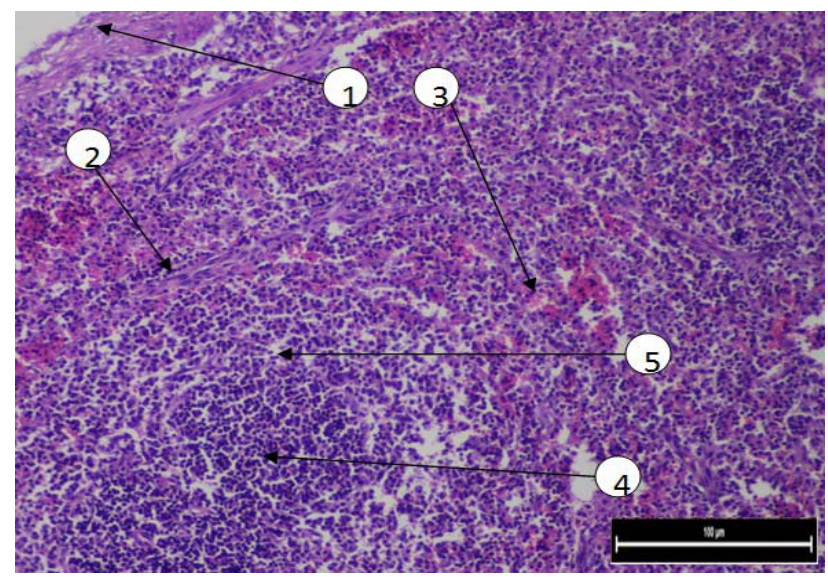

Рис. 1. Селезінка дослідної тварини. Капсула (1).

Трабекули (2). Червона пульпа (3). Центральна (4) i

периферична (5) частини лімфоїдного вузлика.

Фарбування гематоксиліном Караці та еозином, х 100

Варто зазначити, що більшість лімфоїдних вузликів мали округлу, а деякі - овально-видовжену форму (рис. 3) або навіть неправильну (рис. 2). Червона пульпа складалася 3 великої кількості лімфоїдних клітин та еритроцитів (рис. 5), найбільшу кількість яких виявляли у зонах, що прилягали до місць розташування лімфоїдних вузликів. Траплялися також клітини моноцитарно-макрофагального ряду, еозинофіли. Подекуди в полі зору траплялися мегакаріоцити. 3 боку строми селезінки (капсули, трабекул) змін не виявляли.

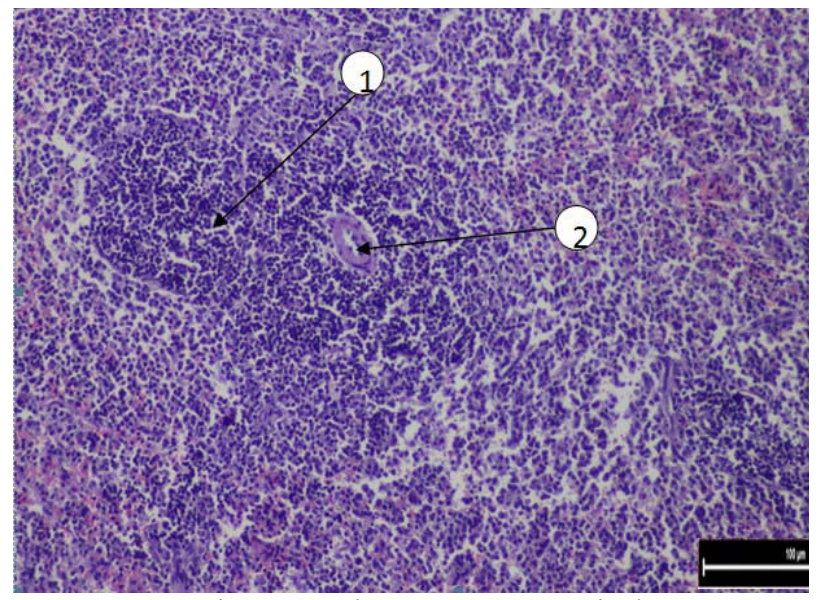

Рис. 2. Селезінка дослідної тварини. Лімфоїдний вузлик неправильної форми (1). Центральна артерія (2). Фарбування гематоксиліном Караці та еозином, х 100

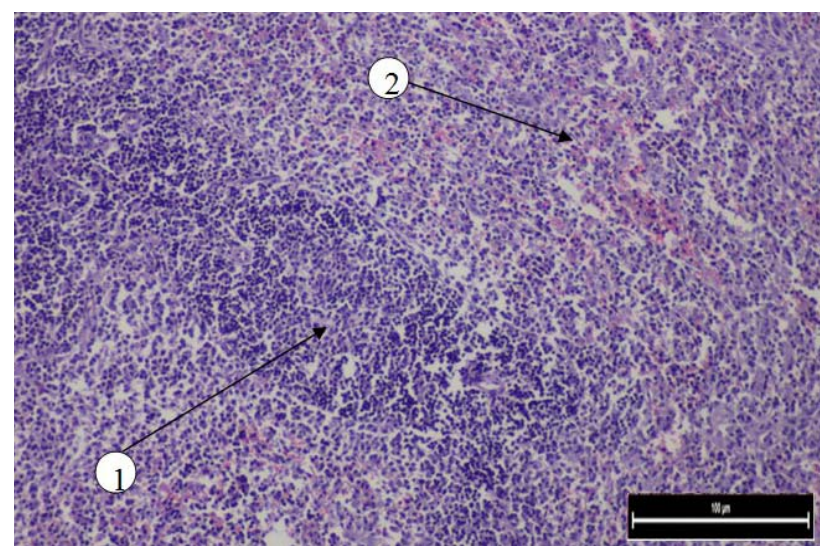

Рис. 3. Селезінка дослідної тварини. Лімфоїдний вузлик овально-видовженої форми (1). Червона пульпа (2). Фарбування гематоксиліном Караці та еозином, х 100

Встановлено, що кровонаповнення артерій було меншим, ніж у нормі. На деяких препаратах за великих збільшень в червоній пульпі виявляли включення білірубіну (рис. 4).

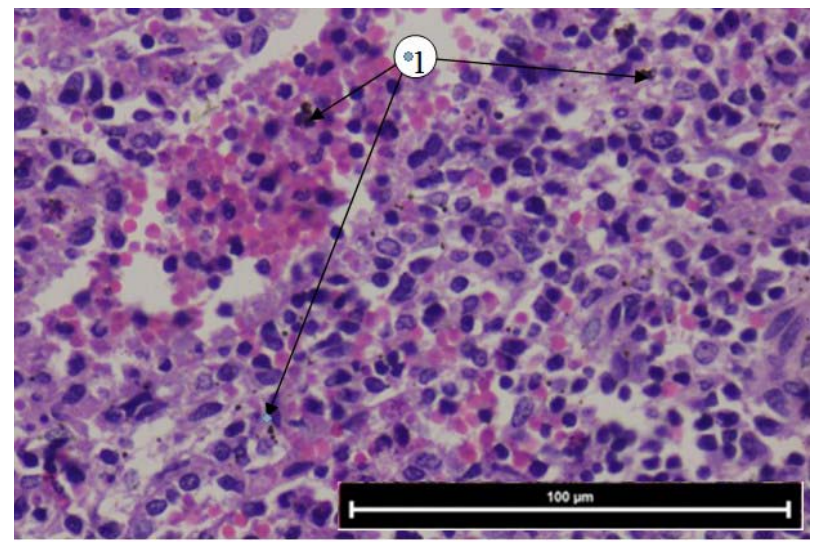

Рис. 4. Селезінка дослідної тварини. Гранули білірубіну (1). Фарбування гематоксиліном Караці та еозином, х 400

У печінці майже всі гепатоцити були патологічно зміненими. Переважна більшість ї була збільшена в розмірах, цитоплазма їхня була неоднорідною, зернистою, розпадалася на окремі глибчасті фрагменти (рис. 5). Деякі гепатоцити мали в цитоплазмі окремі ділянки, які не зафарбовувалися i, вочевидь, являли собою включення ліпідів. В міжчасточковій сполучній тканині виявляли дифузну лімфогістіоцитарну інфільтрацію (рис. 6).

3 боку слизової оболонки жовчних ходів змін не виявляли (рис. 7). У власній їх пластинці виявлено ділянки, де колагенові волокна розволокнені або й зруйновані. На окремих препаратах в міжчасточковій сполучній тканині спостерігали крапкові крововиливи, ділянки навколо них були просочені трансудатом (рис. 7). 


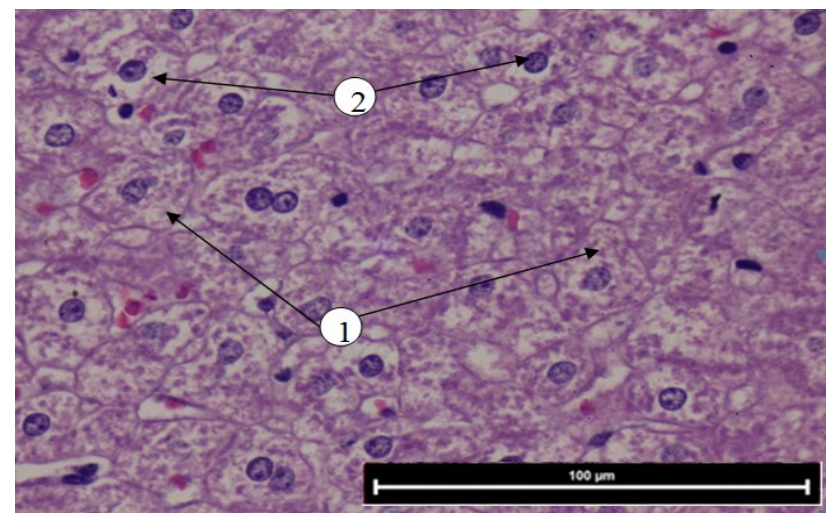

Рис. 5. Печінка дослідної тварини. Гепатоцити у стані зернистої (1) та жирової декомпозитивної (2) дистрофії. Фарбування гематоксиліном Караці та еозином, х 400

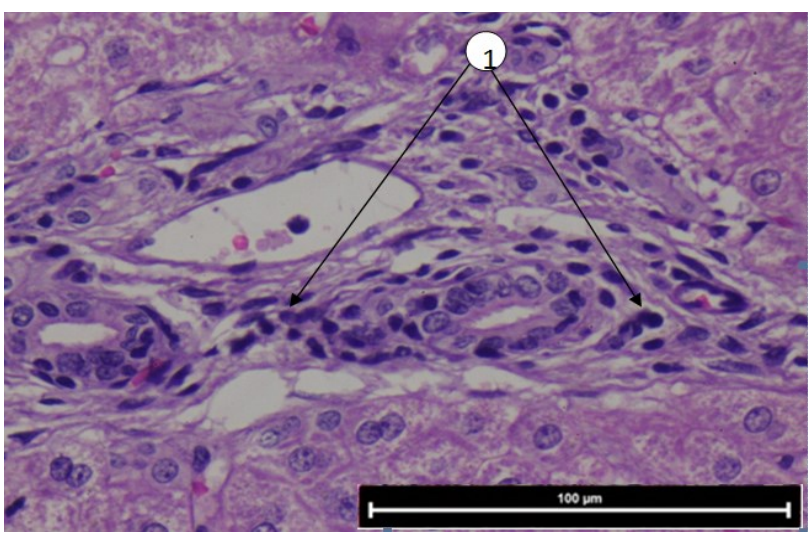

Рис. 6. Печінка дослідної тварини. Лімфогістіоцитарна інфільтрація міжчасточкової сполучної тканини (1). Фарбування гематоксиліном Караці та еозином, x 400

Виражені мікроскопічні зміни виявили у нирках. Ниркові тільця були збільшені в розмірах. В більшості 3 них між судинними клубочками та капсулою виявляли досить великі простори (рис. 8), заповнені прозорою субстанцією, що містила фрагменти судин та клітин (детрит) (рис. 9).

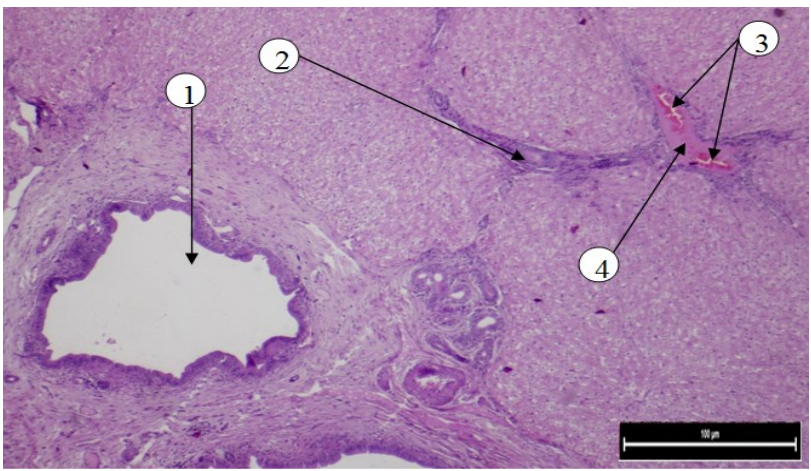

Рис. 7. Печінка дослідної тварини. Жовчний хід (1). Лімфогістіоцитарна інфільтрація (2), крововиливи (3) та набряк (4) Фарбування гематоксиліном Караці та еозином, х 100
Епітеліоцити капсули подекуди були зруйновані. Всередині клубочків виявляли крапкові крововиливи. Спостерігали руйнування окремих подоцитів (рис. 9) та мезангіоцитів (рис. 8).

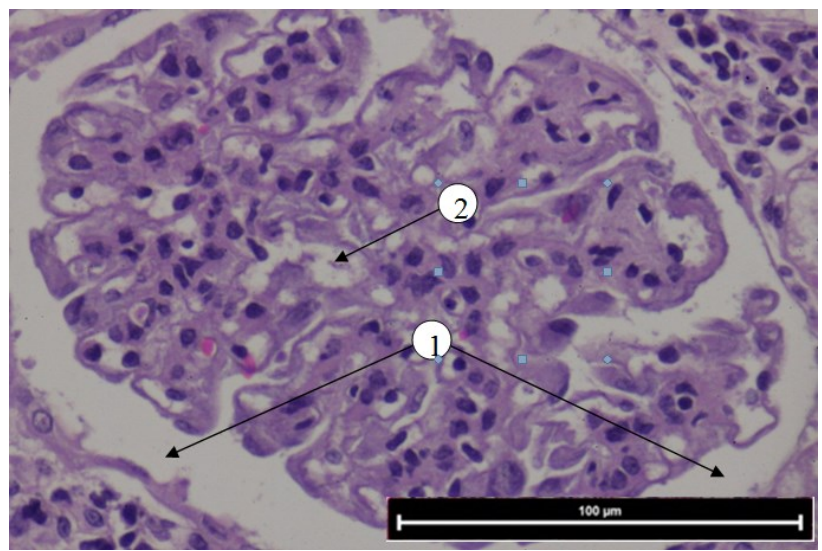

Рис. 8. Нирка дослідної тварини. Серозний ексудат між капсулою та клубочком (1). Руйнування мезангіоцитів (2). Фарбування гематоксиліном Караці та еозином, х 400

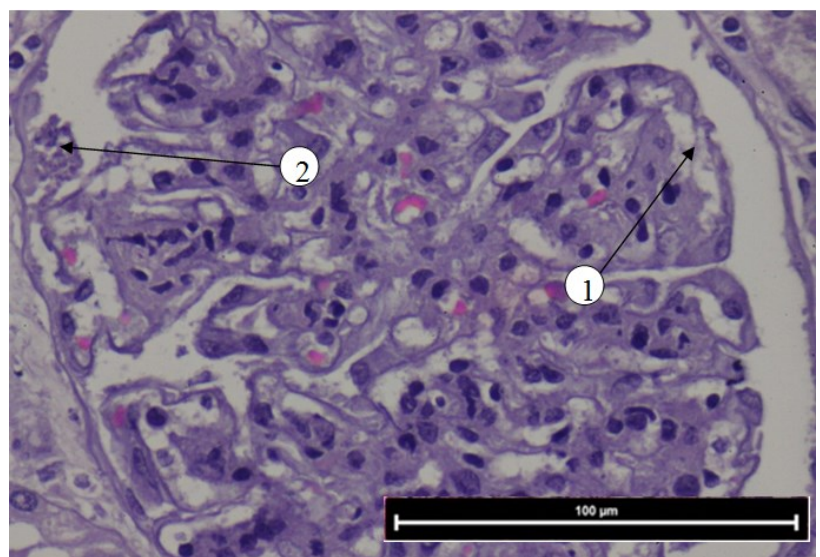

Рис. 9. Нирка дослідної тварини. Руйнування подоцитів (1). Детрит в просторі між клубочком та капсулою (2). Фарбування гематоксиліном Караці та еозином, х 400

У просвітах канальців часто виявляли скупчення еозинофільної маси (білкові циліндри) (рис. 10), що інколи містили й певну кількість еритроцитів. Іноді в канальцях спостерігали руйнування епітеліоцитів, фрагменти яких містилися в просвіті (рис. 11). В інтерстиційній тканині виявляли дифузну лімфогістіоцитарну інфільтрацію (рис. 10).

Епітеліоцити канальців збільшені в розмірах і подекуди мали не кубічну, а циліндричну форму, просвіти таких канальців були відповідно зменшені. Цитоплазма епітеліоцитів канальців в одних випадках була неоднорідною, мутно-сірою; в інших - мала досить великі ділянки, які не зафарбовувалися i, вочевидь, являли собою включення ліпідів (які вимиваються з клітин внаслідок дії розчинників під час виготовлення гістопрепаратів). 


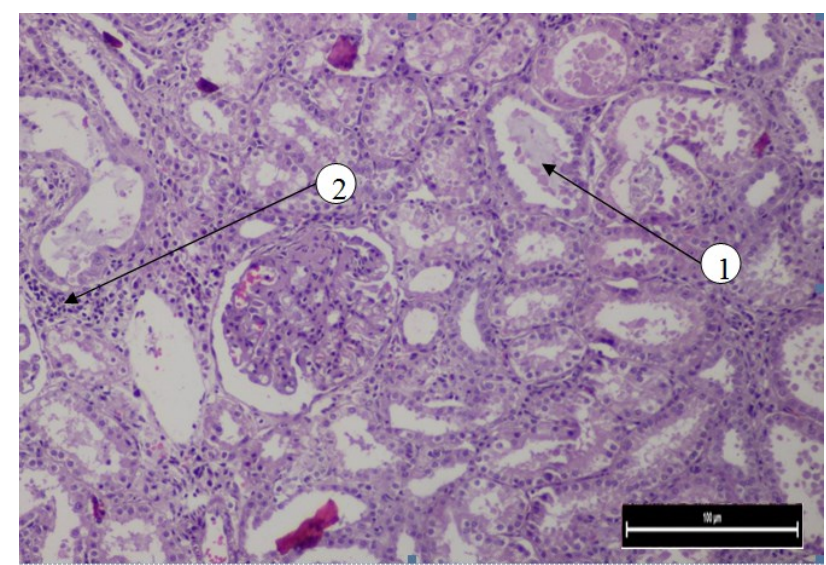

Рис. 10. Нирка дослідної тварини. Білковий циліндр в просвіті канальця (1). Лімфогістіоцитарна інфільтрація інтерстиційної тканини (2).

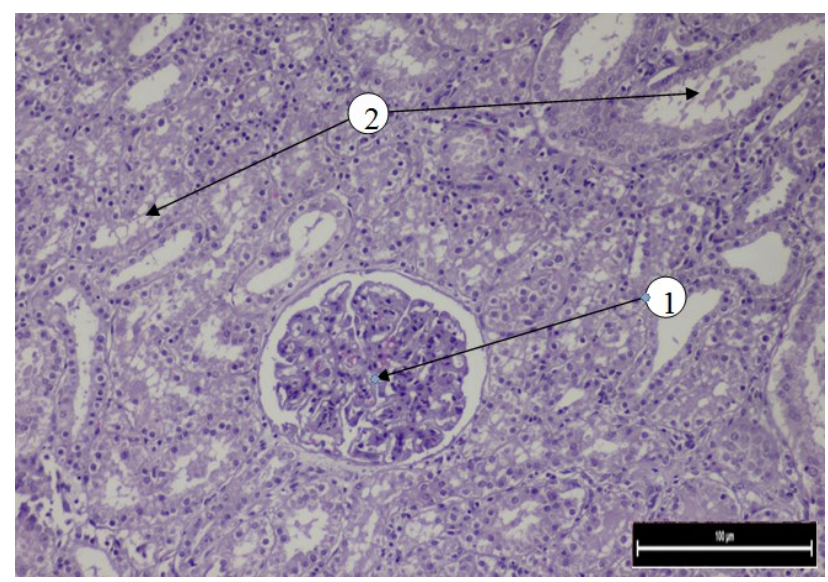

Рис. 11. Нирка дослідної тварини. Уражене ниркове тільце (1). Детрит в просвіті канальців (2).

Фарбування гематоксиліном Караці та еозином, х 100

Проаналізувавши доступну літературу, з'ясовано, що кількість публікацій з патоморфології пасалурозу обмежена. Так, D.D. Florian (1997) зазначав, що за гострого перебігу пасалурозу (II = 9257 екземплярів) макроскопічно виявляли незначне відкладення жирової тканини в підшкірній клітковині, сальнику, капсулі печінки. Брижові лімфовузли збільшені, набряклі й помірно гіперемійовані. Гістологічні дослідження довели, що основні структурні зміни зосереджені в товстій кишці, картина характерна для серознокатарального коліту.

\section{Висновки}

Встановлено, що у кролів за хронічного перебігу пасалурозу розвивається характерний комплекс патоморфологічних змін у паренхіматозних органах, а саме: в селезінці - гіперплазія лімфоїдних вузликів; в нирках - серозний екстракапілярний гломерулонефрит, білковий нефроз за типом зернистої дистрофії, ліпоїдний нефроз, некротичний нефроз, дифузний лімфогістіоцитарний інтерстиційний нефрит; у печінці - зерниста й жирова дистрофія гепатоцитів та лімфогістіоцитарний інтерстиційний гепатит.
Перспективи подальших досліджень. В подальшому планується детальне вивчення особливостей мікроскопічної будови інших органів кролів за пасалурозу.

\section{References}

Darzi, M.M., Mir, M.S., Kamil, S.A., Nashiruddullah, N., \& Munshi, Z.H. (2007). Pathological changes and local defense reaction occurring in spontaneous hepatic coccidiosis in rabbits (Oryctolagus cuniculus). World Rabbit Science, 15(1), 23-28. doi: 10.4995/wrs.2007.608.

Eira, C., Torres, J., Miquel, J., \& Vingada, J. (2007). The helminth parasites of the wild rabbit Oryctolaguscuniculus and their effect on host condition in Dunas de Mira, Portugal. Journal of Helminthology, 81(3), 239246. doi: $10.1017 / \mathrm{S} 0022149 \mathrm{X} 07727426$.

Elshahawy, I., \& Elgoniemy, A. (2018). An Epidemiological Study on Endoparasites of Domestic Rabbits (Oryctolaguscuniculus) in Egypt with Special Reference to Their Health Impact. Sains Malaysiana, 47(1), 9-18. doi: 10.17576/jsm-2018-4701-02.

Florian, D.D. (1997). Passaluroz krolikov v usloviyah Moskovskoy oblasti: Biologiya vozbuditelya, epizootologiya i meryi borbyi [Passalurosis of rabbits in the conditions of the Moscow region: Pathogen biology, epizootology and control measures]. Moscow (in Russian).

Goral's'kyj, L.P., Homych, V.T., \& Konons'kyj, O.I. (2005). Osnovy gistologichnoi' tehniky i morfofunkcional'ni metody doslidzhen' u normi ta pry patologii' [Fundamentals of histological technique and morphofunctional methods of research in norm and pathology]. Polissja: Zhytomyr (in Ukrainian).

Kos'yanchuk, N.I. (2017). The rabbits myxomatosis prophylaxis Scientific Messenger LNUVMBT named after S. Z. Gzhytskyj, 19(73), 145-148. doi: 10.15421/nvlvet7330 (in Ukrainian).

Laakkonen, J., Nyyssönen, T., Hiltunen. M., Kauhala. K., Nikander, S., \& Soveri T. (2006). Effects of Protostrongylus sp. and Pneumocystis sp. on the pulmonary tissue and the condition of mountain and brown hares from Finland. Journal of Wildlife Diseases, 42(4), 780-787. doi: 10.7589/0090-3558-42.4.780.

Lello, J., Boag, B. \& Hudson, P.J. (2005). The effect of single and concomitant pathogen infections on condition and fecundity of the wild rabbit (Oryctolaguscuniculus). International Journal of Parasitology, 35(4), 1509-1515. doi: 10.1016/j.ijpara.2005.06.002

Motamedi, G., Moharami, M., Paykari, H., Eslampanah, M., \& Omraninava, A. (2014). A. Survey on the Gastrointestinal Parasites of Rabbit and Guinea Pig in a Laboratory Animal House. Archives of Razi Institute, 69(1), 77-81. doi: 10.7508/ari.2014.01.011.

Nagashyan, O.Z., \& Tscherbakov, O.V. (2005). Endoparasity i associativnyi invasii krolikov $\mathrm{V}$ Armenii [Enodoparasites and associative invasions of rabbits in Armenia]. Veterinarna medicina: mizhvid. 
Temat. nauk. zb. Kharkiv, 85(2), 809-810 (in Russian).

Okumu, P.O., Gathumbi, P.K., Karanja, D.N., Mande, J.D., Wanyoike, M.M., Gachuiri, C.K., Kiarie, N., Mwanza, R.N., \& Borter, D.K. (2014). Prevalence, pathology and risk factors for coccidiosis in domestic rabbits (Oryctolagus cuniculus) in selected regions in Kenya. Veterinary Quarterly, 34(4), 205-210. doi: 10.1080/01652176.2014.978044.

Ola-Fadunsin, S.D., Hussain, K., Rabiu, M., \& Ganiyu, I.A. (2018). Parasitic conditions of domestic owned rabbits in Osun State, southwestern Nigeria: Retrospective evaluation, risk factors and co-infestations. International Journal of Veterinary Science and Medicine, 6(2), 208-212. doi: 10.1016/j.ijvsm.2018.06.002.

Rewatkar, S.G., Deshmukh, S.S., Kumar, P.G., Maske, D.K., \& Bhangale, G.N. (2013). Occurrence of gastrointestinal helminthes in rabbits with special reference to importance of Giardia spp. As parasitic zoonoses. Science, Technology and Arts Research Journal, 2(3), 142-143. doi: 10.4314/star.v2i3.98754.

Sharma, R., Kapoor, D., \& Kumar, R. (2017). A rare case of verminous pneumonia in domestic rabbit. Journal of Parasitic Diseases, 41(3), 716-717. doi: 10.1007/s12639-016-0875-1.

Sürsal, N., Gökpinar, S., \& Yildiz, K. (2014). Prevalence of intestinal parasites in hamsters and rabbits in some pet shops of Turkey. Turkiye Parazitol Derg, 38(2), 102-105. doi: 10.5152/tpd.2014.3338.

Szkucik, K., Pyz-Łukasik, R., Szczepaniak, K.O., \& Paszkiewicz, W. (2014). Occurrence of gastrointestinal parasites in slaughter rabbits. Parasitol Res., 113(1), 59-64. doi: 10.1007/s00436-013-3625-7.

Zon, H.A., Skrypka, M.V., \& Ivanivska, L.B. (2009). Patolohoanatomichnyi roztyn tvaryn [Pathogeanatomical section of animals]. Donetsk (in Ukrainian). 